\title{
Optimization of the Alcoholic Concentration Obtained From Sugary Cassava (Manihot esculenta Crantz) by Response Surface Methodology
}

\author{
Rodrigo O. Aguiar ${ }^{1}$, Amanda G. P. Carréra ${ }^{1}$, Roberto L. Cunha ${ }^{2}$, Igor V. de Oliveira ${ }^{3}$, Claudete R. da Silva ${ }^{1}$, \\ Vicente F. A. Silva ${ }^{1}$, José N. da Silva ${ }^{1}$, Josiane P. da Silva ${ }^{1}$, Fábio I. M. Carvalho ${ }^{1}$, Luiza H. da S. Martins ${ }^{1}$, \\ Priscilla A. Silva ${ }^{1} \&$ Elisa F. Moura ${ }^{2}$ \\ ${ }^{1}$ Federal Rural University of the Amazon, Belém, Brazil \\ ${ }^{2}$ Laboratory of Sustainable Systems Analysis, Embrapa Eastern Amazon, Belém, Brazil \\ ${ }^{3}$ Federal University of South and Southeast Pará, Marabá, Brazil \\ Correspondence: Priscilla A. Silva, Federal Rural University of the Amazon, Belém, PA, Brazil. Tel: \\ 55-91-981-443-174. E-mail: prisciandra@yahoo.com.br
}

Received: August 15, 2020

doi:10.5539/jas.v12n11p157
Accepted: September 21, $2020 \quad$ Online Published: October 15, 2020

URL: https://doi.org/10.5539/jas.v12n11p157

\begin{abstract}
Sugary cassava or mandiocaba is a cassava variety of potential use for bioethanol production. In this study, laboratory-scale fermentations were carried out in a bioreactor with a working volume of $1 \mathrm{~L}$, using the yeast strain LNF CAT-1. A central composite design (CCD) was applied to determine the extent to which $\mathrm{pH}$, temperature, and yeast concentration influence ethanol production with the aim of improving the fermentation process. The individual effects and the interaction of these factors were analyzed using a surface response method. Physicochemical properties of the material were also investigated and the analysis of root characterization showed high moisture content $(\sim 91 \%)$ and a low amount of starch $(\sim 4.0 \%)$, ash values close to $1.0 \%$, total fibers $0.4 \%$, proteins $0.15 \%$, and lipids $0.1 \%$. The results obtained from the wort presented a low acidity $(\sim 0.2 \%), \mathrm{pH}$ close to neutrality $(\sim 6.5 \%)$, total soluble solids values of $\sim 5.8 \%$, glucose content $\sim 2.3 \%$, fructose $\sim 1.0 \%$, and sucrose $\sim 1.2 \%$. The second-order polynomial regression model determined that the maximum ethanol production of $2.8 \%(\mathrm{v} / \mathrm{v})$ would be obtained when the optimum $\mathrm{pH}$, temperature, and yeast concentration were $\sim 5.0,32-36{ }^{\circ} \mathrm{C}$, and $\sim 10-14 \mathrm{~g} \mathrm{~L}^{-1}$, respectively.
\end{abstract}

Keywords: central composite design, bioethanol, alcoholic fermentation, characterization

\section{Introduction}

The development of sustainable energy resources and the reduction of greenhouse gases from fossil fuels have become essential topics of interest worldwide (Pradhan, Mahajani, \& Arora, 2018). It is known that new sources of cheap fossil fuels are no longer available and experts have been issuing warnings about the possible depletion of current sources in the near future (Sipra \& Sarwar, 2018).

It is now clear that the replacement of current fossil energy will require the development of new strategies to reduce our global energy consumption and the development of a panel of renewable energy sources (Carneiro et al., 2017). In this scenario, sustainable biofuel production is a valuable tool to curb climate change (Creutzig et al., 2015).

As an example of biofuel, bioethanol has received increasing attention due to its excellent properties, mature production technology, and widely available raw material. In addition to corn in the United States and China, sugarcane in Brazil and wheat in some European countries, cassava has also been applied to produce bioethanol in many countries, especially tropical countries in Africa, Asia, and Latin America (Kristensen et al., 2014; Zhang et al., 2016).

Cassava (Manihot esculenta Crantz) is grown in more than 100 countries, and Brazil accounted for $6.2 \%$ of world production in 2018, the fifth-largest producer in the world (FAO, 2018). Among the varieties of cassava grown in the Amazon, there is sugary cassava, also known as mandiocaba, used since pre-Columbian times by 
indigenous people. These cultivars have high productivity and high levels of free sugars in their roots (Carvalho et al., 2004; Souza et al., 2013).

However, several physicals (temperature and osmotic pressure), chemical ( $\mathrm{pH}$, oxygenation, inhibitors, and mineral and organic nutrients) and microbiological factors (species, strain, and concentration of yeast and bacterial contamination), affect fermentation yield and conversion efficiency of sugar in ethanol (Lima, Aquarone, Borzani, \& Schimidell, 2001).

The ethanol production process from sugary cassava is similar to that of sugarcane, as it does not require the hydrolysis process, which starch is converted into glucose (Castelo et al., 2004; Wangpor et al., 2017; Fernades, Garcia, Fonseca, Leite, \& Paz, 2020), becoming an alternative to the agroecological zoning of sugarcane imposed on the Amazon biome (Biofuels Watch Center [BWC], 2010). In this context, the present study evaluated the physicochemical properties of sugary cassava wort and root, as well as evaluated the effect of factors such as temperature, $\mathrm{pH}$, and yeast concentration on alcoholic fermentation for ethanol production.

\section{Material and Methods}

\subsection{Feedstock}

The sugary cassava roots used were obtained from the active germplasm bank (AGB) of Embrapa Eastern Amazon, Brazil. Different cultivars were collected (São Francisco, MBA. Paulo Ribeiro, Pirabas 2, Igarapé Açú CAS 3613) and transported to the laboratory for processing, where cleaning was carried out with the help of a brush and running water to remove foreign materials such as sand, straw, leaves, etc. Rotting roots were discarded, as they could influence the response in the fermentation process. The rest of the roots were crushed (with the aid of an industrial crusher) and pressed in synthetic fabric. For studying fermentation, the different cultivars were homogenized in a single sample.

\subsection{Wort Obtaining}

The wort, with approximately $5.8^{\circ} \mathrm{Brix}$, was first pasteurized to eliminate unwanted microorganisms, using a small-scale continuous system, consisting of stainless steel coil, pre-heating bath, constant temperature control, peristaltic pump, and flow speed control.

The binomial time/temperature pasteurization was adjusted in 20 seconds at $90{ }^{\circ} \mathrm{C}$. Then, the wort was cooled and packed in polyethylene bags with a capacity of $1 \mathrm{~L}$. The resulting wort was stored in a cold chamber at $-18 \pm 2{ }^{\circ} \mathrm{C}$ until analysis.

\subsection{Microorganism}

The yeast used was Saccharomyces cerevisiae CAT-1, obtained from LNF Latino Americana, located in Bento Gonçalves (RS), Brazil. The sample with a minimum of $10.10^{9} \mathrm{CFU} \mathrm{g}{ }^{-1}$ live cells and $65 \%$ viable cells were hydrated in the fermentation wort $\left(100 \mathrm{~mL} 5 \mathrm{~min}^{-1}\right.$ at $\left.30^{\circ} \mathrm{C}\right)$ and added to the bioreactor.

It is important to highlight that this microorganism is highly used in Brazil by ethanol producers, as it shows resistance to high ethanol concentration and temperatures, low fermentation time, and remains in the process throughout the season. In addition, this yeast was isolated from ethanol plants in 1998 (Basso, Amorim, Oliveira, \& Lopes, 2008; Santos et al., 2017).

\subsection{Bioreactor and Fermentation Conditions}

Fermentation runs were carried out using a TECNAL ${ }^{\circledR}$ bioreactor, on a laboratory scale with a capacity of $1.5 \mathrm{~L}$. The equipment consists of an aeration chamber, peristaltic pumps, performance measurement modules, and thermostatic bath modules, in addition to a container glass bioreactor with stainless steel lid. The ethanol fermentation runs were performed under semi-sterile conditions. Before each fermentation, the bioreactor was washed with soap and water and sanitized using $1.5 \mathrm{~mL} \mathrm{~L}^{-1}$ of sodium hypochlorite $(2.0-2.5 \% \mathrm{w} / \mathrm{w}$ of active chlorine). After 1 hour, $2 \mathrm{~mL}$ of sodium thiosulfate solution $\left(50 \mathrm{~g} \mathrm{~L}^{-1}\right)$ was added to neutralize residual chlorine. The bioreactor liquid content was then discarded past 30 minutes. After sanitization, $1 \mathrm{~L}$ of wort was added to the bioreactor along with the hydrated yeasts, and fermentation was started, with a constant agitation rate of 100 rpm.

\subsection{Statistical Analysis}

A central composite design (DCC) was performed using Statistica 10 software (StatSoft ${ }^{\circledR}$, USA), with two original levels, $2^{3}$ factorial points, 6 axial points, and 3 central points. In order to determine the best operational conditions for the fermentation process, the variables chosen to be studied were $\mathrm{pH}$, Temperature, and yeast concentration. The $\mathrm{pH}$ varied from 3.1 to 5.9 , temperature from 26.8 to 36.2, and yeast concentration in the 
medium from 3.2 to 16.8 . The alpha value of orthogonality used was 1.35313 and the coding equations for Temperature $\left(\mathrm{X}_{0}\right), \mathrm{pH}\left(\mathrm{Y}_{0}\right)$, and yeast concentration $\left(\mathrm{Z}_{0}\right)$ are shown respectively in Equations 1,2 , and 3 . The runs were performed randomly to avoid bias in the results.

$$
\begin{aligned}
& X_{1}=\frac{\left(X_{0}-31.5\right)}{3.5} \\
& X_{2}=\frac{\left(Y_{0}-4.5\right)}{1} \\
& X_{3}=\frac{\left(Z_{0}-10\right)}{5}
\end{aligned}
$$

\subsection{Analytical Methods}

\subsubsection{Moisture}

The moisture content was determined according to the AOAC method 984.25 (1984). The sample ( $\pm 2 \mathrm{~g})$ was placed in a previously weighed porcelain crucible. Then placed in the oven at $105{ }^{\circ} \mathrm{C}$, cooled in a desiccator, and then weighed. This procedure was repeated until a constant weight was obtained.

\subsubsection{Ashes}

The ash content was determined according to the AOAC method 923.03 (1997). Each dry sample ( \pm 2 g) previously charred was placed in a porcelain crucible, incinerated in a muffle at a temperature of approximately $550{ }^{\circ} \mathrm{C}$ until constant weight.

\subsubsection{Fiber}

The determination of the total fiber content was obtained through the acid detergent method (FDA) according to AOAC, (method 973.18, AOAC, 1997).

\subsubsection{Proteins}

The crude protein content was determined according to AOAC method 920.87 (1997). The total nitrogen content was determined using the Kjeldahl method and the protein content calculated by multiplying the nitrogen value by the general factor 6.25 .

\subsubsection{Lipids}

The total lipid content was determined by the cold extraction method using the Bligh-Dyer method (1959). Before carrying out the analysis, the moisture content of the sample was reduced to approximately $10 \%$, due to a large amount of water present.

\subsubsection{Total Soluble Solids}

The determination of total soluble solids (TSS) consists of the measurement of the solution refractive index. The results were expressed in ${ }^{\circ}$ Brix through the use of a digital refractometer HISEG RTD-45 (0-32 ${ }^{\circ}$ Brix), according to method 932.12 of AOAC (1997).

\subsubsection{Total Reducing Sugars}

The determination of the Total Reducing Sugar (TRS) concentration expressed as glucose, present in the wort, was performed by the Eynon \& Lane method, using the equipment referred to as REDUTEC® (TECNAL, Brazil, model TE-088), for the titration. This method consists of the sum of reducing sugars present in the sample and those from sucrose hydrolysis, according to AOAC method 31.034-6 (1984).

\subsubsection{Determination of Starch, Glucose, Fructose, and Sucrose}

The content of glucose, fructose, and sucrose (soluble sugars), present in the wort during fermentation, was obtained based on the enzymatic method published by Stitt, Lilley, Gerhardt and Heldt (1989), where $100 \mu \mathrm{L}$ buffer containing $200 \mathrm{mM}$ Imidazole, $10 \mathrm{mM} \mathrm{MgCl}$ was placed in each well of the ELISA plate. $4 \mathrm{mM} \mathrm{NAD}^{+}$, $2 \mathrm{mM}$ ATP and $2.4 \mathrm{U}$ of G6PDH; $5 \mu \mathrm{L}$ of extract (samples centrifuged $10000 \mathrm{rpm} 3 \mathrm{~min}^{-1}$ and diluted 1:20) and $90 \mu \mathrm{L}$ of distilled water. Glucose, fructose, and sucrose were quantified by the addition of $5 \mu \mathrm{L}$ of hexokinase $(1.4 \mathrm{U}), 5 \mu \mathrm{L}$ phosphoglucoisomerase $(0.6 \mathrm{U})$, and $5 \mu \mathrm{L}$ invertase $(0.8 \mathrm{U})$, respectively, each time the curve of reaction reached a plateau. The analyzes were performed in triplicate, and the readings were done at $340 \mathrm{~nm}$.

For the quantification of starch, $100 \mathrm{mg}$ of fresh root were homogenized in ethanol $80 \%(\mathrm{v} / \mathrm{v})$, incubated at $70{ }^{\circ} \mathrm{C}$ for $90 \mathrm{~min}$, and subjected to two centrifugations $\left(15000 \mathrm{~g} 10 \mathrm{~min}^{-1}\right)$. The resulting pellet was suspended in $\mathrm{KOH}$ at $95^{\circ} \mathrm{C}$ for one hour, neutralized in acetic acid, and again centrifuged $\left(15000 \mathrm{~g} 10 \mathrm{~min}^{-1}\right)$. The starch was then hydrolyzed in citrate buffer $(100 \mathrm{mM}$ at $\mathrm{pH} 4.6)$ containing amyloglucosidase and $\alpha$-amylase (adapted from Trethewey et al., 1998), and the released glucose was quantified as described above. 


\section{$2.6 .9 \mathrm{pH}$}

The $\mathrm{pH}$ determination was performed using the Mettler toledo electrode model InPro ${ }^{\circledR} 325 \mathrm{x}$ in the fermentation analyzes. For the previous analysis of the wort, the T-1000 bench model meter from Tekna was used. The $\mathrm{pH}$ meters were duly calibrated with the buffer solutions $\mathrm{pH} 7.0$ and 4.0 at $20^{\circ} \mathrm{C}$, according to the AOAC method No. 981.12 (1997).

\subsubsection{Determination of Total Titratable Acidity}

The total titratable acidity was determined by the AOAC method 942.15 (1997). Titration was carried out with $0.1 \mathrm{~mol} \mathrm{~L}^{-1} \mathrm{NaOH}$ until $\mathrm{pH} \pm 8.2$ (referring to the color change $\mathrm{pH}$ of the phenolphthalein indicator). The results were expressed as a percentage of acid per $100 \mathrm{~mL}$ of wort.

\subsubsection{Determination of Ethanol Concentration}

The ethanol concentration was determined by the densimetric method. For distillation, $25 \mathrm{~mL}$ of sample was mixed with $25 \mathrm{~mL}$ of distilled water, collecting $50 \mathrm{~mL}$ of distillate in a micro distiller, model SL. 077 (SOLAB). The samples were collected in sterilized amber glass bottles, promptly frozen, and sent for analysis in a Rudolph digital densimeter, model DDM 2911. Equation 4 was used to calculate the ethanol concentration of the samples.

$$
\text { Ethanol }=\mathrm{L} \times 2
$$

Where, Ethanol is the concentration of ethanol in ${ }^{\circ} \mathrm{GL}\left(\mathrm{v} / \mathrm{v}\right.$ at $\left.20{ }^{\circ} \mathrm{C}\right) ; \mathrm{L}$ is the sample reading on the DDM 2911 digital densimeter; 2 is the sample dilution factor.

\subsection{Fermentative Parameters}

Based on the results obtained from analytical determinations of the initial and fermented wort, calculations of the following fermentation parameters were performed, using Equations 5 and 6.

Equation 5 determined the yield in gram of ethanol per gram of total reducing sugars (TRS), in percentage, after 7 hours of fermentation.

Equation 6 was used to determine productivity, which expresses the average ethanol production speed, after 7 hours of fermentation.

$$
\text { Yield }(\%)=\frac{\mathrm{C}_{\text {ethanol }}}{0.511 \times\left(\mathrm{TRS}_{0}-\mathrm{TRS}_{7}\right)} \times 100
$$

Where, Yield (\%) is the Ethanol Yield (\%); $\mathrm{Cethanol}_{7}$, is the concentration of ethanol $\left(\mathrm{g} \mathrm{L}^{-1}\right)$ at the end of 7 hours of fermentation; $\mathrm{TRS}_{0}$, is the initial reducing sugar $\left(\mathrm{g} \mathrm{L}^{-1}\right)$; and $\mathrm{TRS}_{7}$, is the final reducing sugar $\left(\mathrm{g} \mathrm{L}^{-1}\right)$ after 7 hours of fermentation.

$$
\mathrm{P}_{\text {ethanol }}=\frac{\mathrm{C}_{\text {ethanol }}}{\mathrm{t}}
$$

Where, $\mathrm{P}$ ethanol is the productivity of ethanol $\left(\mathrm{g} \mathrm{L}^{-1} \mathrm{~h}^{-1}\right)$; Cethanol 7 , is the concentration of ethanol $\left(\mathrm{g} \mathrm{L}^{-1}\right)$ at the end of 7 hours of fermentation; and $\mathrm{t}=$ fermentation time $(\mathrm{h})$

\subsection{Determination of Yeast Concentration}

Wort samples were taken from the bioreactor at times $0,0.16,0.36,0.5,1,2,3,4,56$, and $7 \mathrm{~h}$ during fermentation. Then, $2 \mathrm{~mL}$ of previously homogenized suspension was pipetted into a microtube of known tare. The tubes were centrifuged and the soluble part was separated into another tube and frozen until sugar analysis was carried out, the precipitate was, in turn, resuspended and washed twice $\left(10000 \mathrm{rpm} 3 \mathrm{~min}^{-1}\right)$. It was dried to constant weight in an oven at $80^{\circ} \mathrm{C}$. The dry cell mass was then determined by mass difference, and the results were expressed in terms of grams of dry cells $100 \mathrm{~mL}^{-1}$ of suspension (adapted from Sperotto, 2014).

\section{Results}

\subsection{Physicochemical Characterization of Root and Wort}

In the physicochemical composition of the sugary cassava root (Table 1), based on percentage, it was evident a high moisture content and a low amount of starch. 
Table 1. Physicochemical composition of sugary cassava root

\begin{tabular}{ll}
\hline Determination $(\%)$ & Average \pm SD* $^{*}$ \\
\hline Moisture & $90.61 \pm 0.004$ \\
Ashes & $0.11 \pm 0.001$ \\
Total fibers & $0.42 \pm 0.552$ \\
Protein & $0.15 \pm 0.007$ \\
Lipids & $0.09 \pm 0.005$ \\
Starch & $4.22 \pm 0.342$ \\
\hline
\end{tabular}

Note. ${ }^{*}$ The results were expressed as average \pm SD (standard deviation).

Among the main characteristics, of physicochemical composition, found in the sugary cassava wort (Table 2), a low acidity, $\mathrm{pH}$ close to neutrality and a large amount of free sugars stand out.

Table 2. Physicochemical composition of sugary cassava wort

\begin{tabular}{ll}
\hline Determination & Average \pm SD* \\
\hline Acidity** & $0.24 \pm 0.040$ \\
$\mathrm{pH}$ & $6.55 \pm 0.014$ \\
TSS & $5.76 \pm 0.094$ \\
Reducing Sugars (\%) & $3.90 \pm 0.082$ \\
Total Sugars (\%) & $5.53 \pm 0.125$ \\
Glucose (\%) & $2.33 \pm 0.068$ \\
Fructose (\%) & $1.04 \pm 0.088$ \\
Sucrose (\%) & $1.19 \pm 0.044$ \\
\hline
\end{tabular}

Note. $*$ Results were expressed as average $\pm \mathrm{SD}$ (standard deviation); $* *\left(\mathrm{~mL}\right.$ of $\left.\mathrm{NaOH} 100 \mathrm{~g}^{-1}\right)$.

\subsection{Experimental Optimization of Fermentation}

In fermentative runs, the alcoholic concentration\% (v/v) varied from $2.33 \%$ (run 1) to $2.92 \%$ (run 4), with no great variations between the experiment responses (Table 3).

Table 3. Central composite design (CCD) matrix for ethanol production from sugary cassava wort fermentation by CAT-1 yeast strain

\begin{tabular}{|c|c|c|c|c|c|c|c|c|c|}
\hline \multirow{2}{*}{ Run } & \multicolumn{2}{|c|}{$\mathrm{pH}$} & \multicolumn{2}{|c|}{ Temperature $\left({ }^{\circ} \mathrm{C}\right)$} & \multicolumn{2}{|c|}{ Yeast concentration $\left(\mathrm{g} \mathrm{L}^{-1}\right)$} & \multirow{2}{*}{ Ethanol\% (v/v) } & \multirow{2}{*}{ Yield (\%) } & \multirow{2}{*}{ Productivity $\left(\mathrm{g} \mathrm{L}^{-1} \mathrm{~h}^{-1}\right)$} \\
\hline & Coded & Real & Coded & Real & Coded & Real & & & \\
\hline 1 & -1 & 3.50 & -1 & 28.00 & -1 & 5.00 & 2.33 & 73.52 & 2.63 \\
\hline 2 & -1 & 3.50 & -1 & 28.00 & 1 & 15.00 & 2.52 & 71.99 & 2.84 \\
\hline 3 & -1 & 3.50 & 1 & 35.00 & -1 & 5.00 & 2.57 & 79.21 & 2.90 \\
\hline 4 & -1 & 3.50 & 1 & 35.00 & 1 & 15.00 & 2.92 & 82.67 & 3.29 \\
\hline 5 & 1 & 5.50 & -1 & 28.00 & -1 & 5.00 & 2.72 & 79.67 & 3.07 \\
\hline 6 & 1 & 5.50 & -1 & 28.00 & 1 & 15.00 & 2.70 & 77.78 & 3.05 \\
\hline 7 & 1 & 5.50 & 1 & 35.00 & -1 & 5.00 & 2.53 & 72.30 & 2.85 \\
\hline 8 & 1 & 5.50 & 1 & 35.00 & 1 & 15.00 & 2.66 & 75.86 & 3.00 \\
\hline 9 & $-\alpha$ & 3.15 & 0 & 31.50 & 0 & 10.00 & 2.74 & 77.45 & 3.09 \\
\hline 10 & $+\alpha$ & 5.85 & 0 & 31.50 & 0 & 10.00 & 2.86 & 81.03 & 3.23 \\
\hline 11 & 0 & 4.50 & $-\alpha$ & 26.76 & 0 & 10.00 & 2.56 & 72.82 & 2.89 \\
\hline 12 & 0 & 4.50 & $+\alpha$ & 36.24 & 0 & 10.00 & 2.83 & 80.20 & 3.19 \\
\hline 13 & 0 & 4.50 & 0 & 31.50 & $-\alpha$ & 3.23 & 2.56 & 76.05 & 2.89 \\
\hline 14 & 0 & 4.50 & 0 & 31.50 & $+\alpha$ & 16.77 & 2.69 & 77.24 & 3.03 \\
\hline $15(\mathrm{C})$ & 0 & 4.50 & 0 & 31.50 & 0 & 10.00 & 2.71 & 77.18 & 3.06 \\
\hline $16(\mathrm{C})$ & 0 & 4.50 & 0 & 31.50 & 0 & 10.00 & 2.78 & 80.07 & 3.14 \\
\hline $17(\mathrm{C})$ & 0 & 4.50 & 0 & 31.50 & 0 & 10.00 & 2.84 & 81.87 & 3.20 \\
\hline
\end{tabular}

In the optimization of the ethanol production process, the significance level $p \leq 0.1$ was considered, due to the great variability of the experimental data inherent to bioprocesses. The experiments were evaluated for pure error 
and a complete second-order polynomial model for data adjustments was proposed.

The analysis of variance (ANOVA) for ethanol concentration (Table 4), provided a coefficient of determination $\mathrm{R}^{2}$ (correlation coefficient) of 0.94 significant $(\mathrm{p} \leq 0.1)$, indicating a good fit to the data.

Table 4. Analysis of variance (ANOVA) for ethanol concentration corresponding to the 17 fermentation runs

\begin{tabular}{lllllll}
\hline SV & SS & DF & MS & Fcalc & Ftab & $\mathrm{R}^{2}(\%)$ \\
\hline Treatment/Regression & 0.346423 & 9 & 0.038491 & 13.41633 & 2.724678 & 94.52 \\
Residue & 0.020083 & 7 & 0.002869 & & & \\
Lack of fit & 0.011616 & 5 & 0.002323 & 0.548783 & 9.292626 & \\
Pure error & 0.008467 & 2 & 0.004233 & & & \\
Total & 0.366506 & 16 & & & & \\
\hline
\end{tabular}

Note. $\mathrm{SV}=$ source of variation; $\mathrm{SS}=$ sum of squares; DF = degrees of freedom; MS = mean square; F tab $=$ tabulated F; F calc $=$ calculated F; coefficient of determination $\mathrm{R}^{2}=0.9452($ explained variance $=94.52 \%)$.

Since the model was significant, the effects of the independent variables on the response were analyzed (Table $5)$.

Table 5. Estimated effects and associate $\mathrm{p}$-values for $\mathrm{pH}$, temperature, yeast concentration, and their interactions

\begin{tabular}{lllll}
\hline Mean/Interaction & Effect & Error & $\mathrm{t}(2)$ & $\mathrm{p}$-value \\
& $2.789654^{*}$ & $0.033770^{*}$ & $82.60808^{*}$ & $0.000147^{*}$ \\
\hline$(1) \mathrm{pH}(\mathrm{L})$ & 0.074152 & 0.038105 & 1.94596 & 0.191060 \\
$\mathrm{pH}(\mathrm{Q})$ & -0.006900 & 0.050255 & -0.13730 & 0.903367 \\
(2) Temperature (L) & $0.132970^{*}$ & $0.038105^{*}$ & $3.48954^{*}$ & $0.073218^{*}$ \\
Temperature (Q) & -0.121595 & 0.050255 & -2.41955 & 0.136658 \\
$(3)$ Yeast concentration (L) & $0.141642^{*}$ & $0.038105^{*}$ & $3.71711^{*}$ & $0.065360^{*}$ \\
Yeast concentration (Q) & $-0.198057^{*}$ & $0.050255^{*}$ & $-3.94105^{*}$ & $0.058766^{*}$ \\
$1 \mathrm{~L} \times 2 \mathrm{~L}$ & $-0.217500^{*}$ & $0.046007^{*}$ & $-4.72752^{*}$ & $0.041949^{*}$ \\
$1 \mathrm{~L} \times 3 \mathrm{~L}$ & -0.107500 & 0.046007 & -2.33659 & 0.144494 \\
$2 \mathrm{~L} \times 3 \mathrm{~L}$ & 0.077500 & 0.046007 & 1.68452 & 0.234120 \\
\hline
\end{tabular}

Note. * Significant values at the level of $1 \%(\mathrm{p} \leq 0.1)$; (L): linear term; $(\mathrm{Q})$ : quadratic term.

\subsection{Proposal for a Second-Degree Polynomial Model}

Based on the regression data of the experiment (Table 6), it was possible to develop a mathematical model for the Ethanol variable, through which it is possible to establish the optimal conditions for design, determining the critical or stationary point of the model.

Table 6. Regression coefficient for the Ethanol response

\begin{tabular}{lllll}
\hline & Coefficient of Regression & Deviation & $\mathrm{t}(2)$ & $\mathrm{p}$-value \\
\hline Mean/Interaction & $-7.69838^{*}$ & $2.332814^{*}$ & $-3.30004^{*}$ & $0.080846^{*}$ \\
$(1) \mathrm{pH}(\mathrm{L})$ & $1.15438^{*}$ & $0.310620^{*}$ & $3.71636^{*}$ & $0.065383^{*}$ \\
$\mathrm{pH}(\mathrm{Q})$ & -0.00345 & 0.025128 & -0.13730 & 0.903367 \\
$(2)$ Temperature $\left({ }^{\circ} \mathrm{C}\right)(\mathrm{L})$ & $0.44935^{*}$ & $0.133330^{*}$ & $3.37019^{*}$ & $0.077894^{*}$ \\
Temperature $\left({ }^{\circ} \mathrm{C}\right)(\mathrm{Q})$ & -0.00496 & 0.002051 & -2.41955 & 0.136658 \\
$(3)$ Yeast concentration $\left(\mathrm{g} \mathrm{L}^{-1}\right)(\mathrm{L})$ & 0.07201 & 0.050614 & 1.42278 & 0.290760 \\
Yeast concentration $\left(\mathrm{g} \mathrm{L}^{-1}\right)(\mathrm{Q})$ & $-0.00396^{*}$ & $0.001005^{*}$ & $-3.94105^{*}$ & $0.058766^{*}$ \\
$1 \mathrm{~L} \times 2 \mathrm{~L}$ & $-0.03107^{*}$ & $0.006572^{*}$ & $-4.72752^{*}$ & $0.041949^{*}$ \\
$1 \mathrm{~L} \times 3 \mathrm{~L}$ & -0.01075 & 0.004601 & -2.33659 & 0.144494 \\
$2 \mathrm{~L} \times 3 \mathrm{~L}$ & 0.00221 & 0.001314 & 1.68452 & 0.234120 \\
\hline
\end{tabular}

Note. *Significant values at the level of $1 \%(\mathrm{p} \leq 0.1)$; (L): linear term; $(\mathrm{Q})$ : quadratic term. 
Equation 7 illustrates the statistical model adjusted to the experimental data tested for the ethanol concentration.

$$
\begin{aligned}
\text { Ethanol } & =-7.698+1.154 \mathrm{X}_{1}-0.003 \mathrm{X}_{1}^{2}+0.449 \mathrm{X}_{2}-0.005 \mathrm{X}_{2}^{2}+0.072 \mathrm{X}_{3} \\
& -0.004 \mathrm{X}_{3}^{2}-0.03 \mathrm{X}_{1} \mathrm{X}_{2}-0.011 \mathrm{X}_{1} \mathrm{X}_{3}+0.002 \mathrm{X}_{2} \mathrm{X}_{3}
\end{aligned}
$$

Where, Ethanol represents the concentration of Ethanol\% $(\mathrm{v} / \mathrm{v}), \mathrm{X}_{1}$ is the $\mathrm{pH} ; \mathrm{X}_{2}$ is the Temperature $\left({ }^{\circ} \mathrm{C}\right)$ and $\mathrm{X}_{3}$ is the yeast concentration $\left(\mathrm{g} \mathrm{L}^{-1}\right)$.

This equation can be used to predict alcoholic concentration. In addition to explaining the linear effects of temperature, $\mathrm{pH}$, and yeast concentration on ethanol production. The analysis also described the quadratic and interaction effects of the parameters.

\subsection{Response and Contour Surface Analysis}

The relationship between independent and dependent variables was illustrated in a three-dimensional response surface graphics and two-dimensional contour graphics, generated from the second-order model. The response surface curves were plotted to demonstrate the interactions of the independent variables and to determine the optimal value of each independent variable for the maximum response.

The function of the 3D response surface (Figure 1A) and the contour graphs (Figure 1B) show the effect of pH and temperature on the concentration of ethanol. The ethanol content was higher when $\mathrm{pH}$ levels were below 4.0 combined with temperature values above $34{ }^{\circ} \mathrm{C}$, however, temperatures below $34{ }^{\circ} \mathrm{C}$ in synergy with $\mathrm{pH}$ above 5.5 resulted in slightly lower values of ethanol. The relationship between yeast concentration and $\mathrm{pH}$ is shown in Figures $1 \mathrm{C}$ and 1D.

Based on the response surface, the highest concentration of ethanol was achieved at yeast concentrations between 8 and $14 \mathrm{~g} \mathrm{~L}^{-1}$, over a wide range of $\mathrm{pH}$ values. According to the response acquired for the yeast concentration in this study, it was possible to find a maximum point, which when exceeded, negatively influenced ethanol production. In addition, higher levels of ethanol were produced at temperatures between 32 and $36^{\circ} \mathrm{C}$, and the yeast concentration between 10 and $14 \mathrm{~g} \mathrm{~L}^{-1}$ (Figures $1 \mathrm{E}$ and $1 \mathrm{~F}$ ).

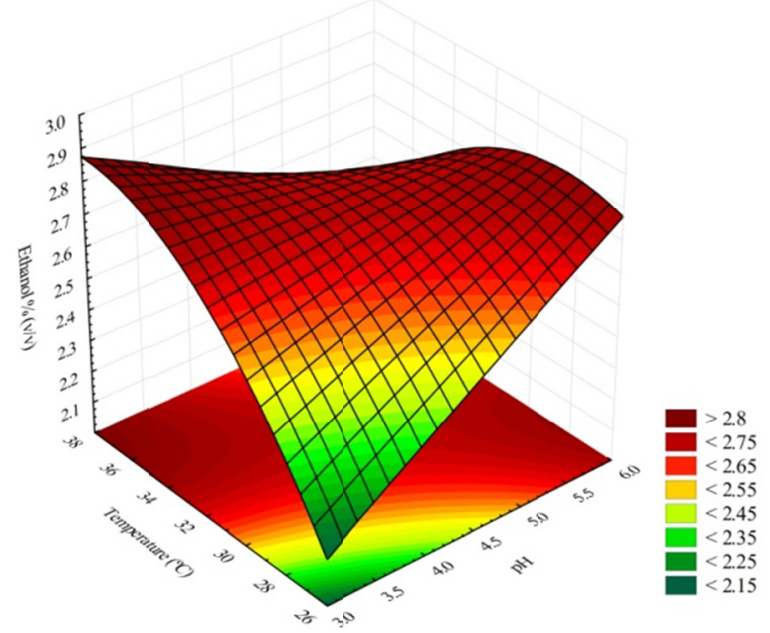

A.

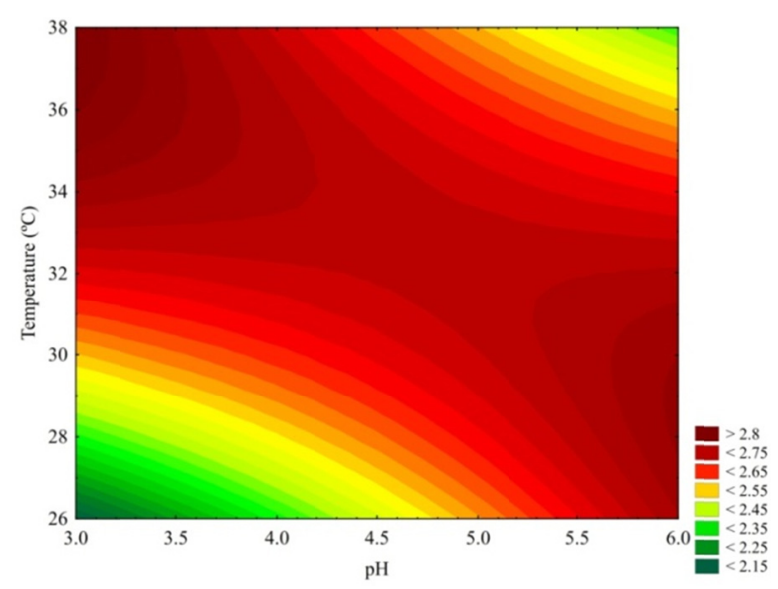

B. 


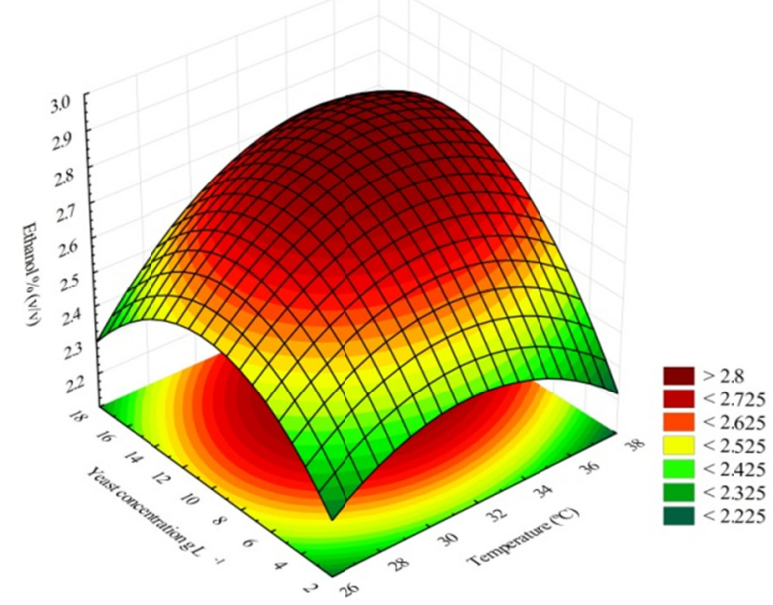

C.

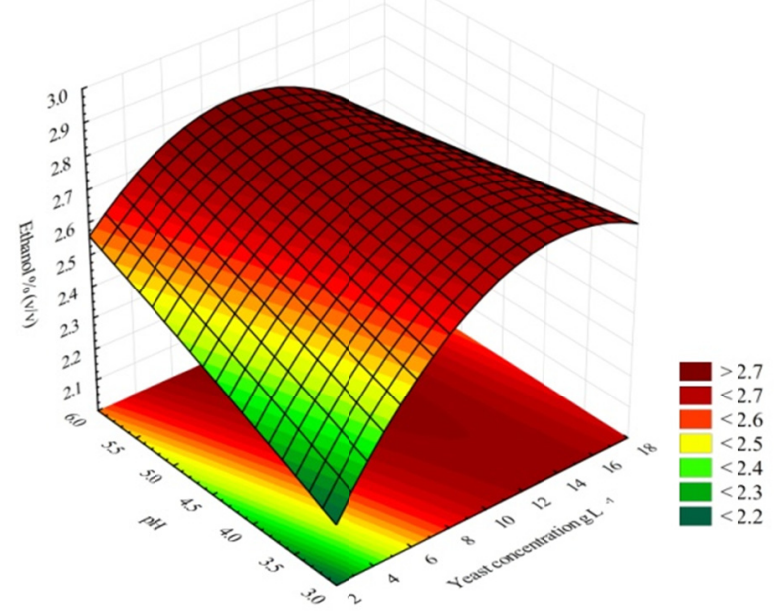

E.

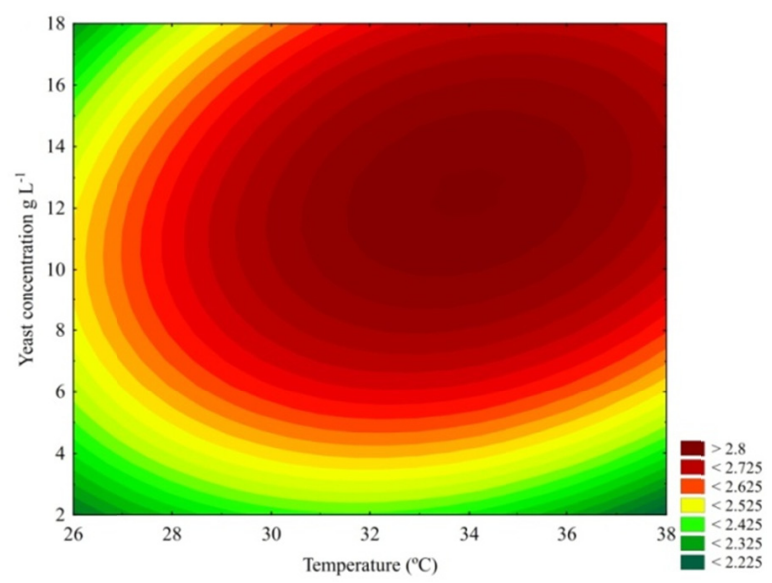

D.

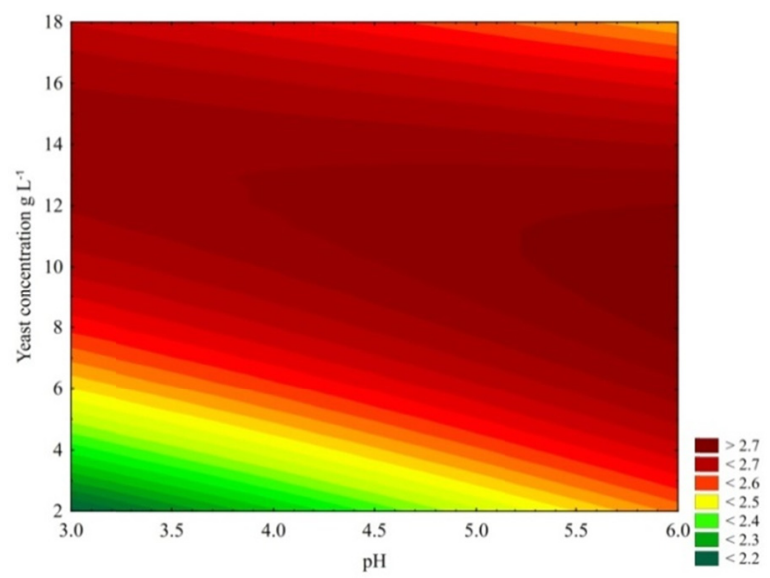

F.

Figure 1. Response surfaces and contour curves of the central composite design evaluating the variables $\mathrm{pH}$, temperature, and yeast concentration in response to ethanol yield

\subsection{Model Reproducibility}

After obtaining the optimum conditions by the response surface method, we determined the kinetics behavior from sugary cassava fermentation (Figure 2). The main objective of this step was to verify whether the results indicated by the model would be reproducible. Fermentation was conducted until the sugar concentration decrease and yeast cell mass stabilize. The $\mathrm{pH}$ values remained practically constant during the process $(\sim 4.5)$. The consumption of free sugars (glucose and fructose) was low during the first hour and increased markedly up to 5 hours of fermentation, ending in a total time of $\sim 7$ hours with a residual concentration of sugars estimated around $0.036 \mathrm{~g} \mathrm{~L}^{-1}$. It noteworthy that after the depletion of sucrose, the consumption of glucose and fructose increased slightly. In addition, it is noted that all sucrose concentration decreased before the consumption of all free glucose in the medium.

The concentration of the yeast increased during the first two hours of the initial fermentation process and remained constant until the end. The final concentration of ethanol found was $2.79 \pm 0.05 \%(\mathrm{v} / \mathrm{v})$, showing good agreement with that predicted by the model $(2.81 \% \mathrm{v} / \mathrm{v})$. As a result, at the end of the experiment, we obtained a yield of $78.3 \%$ and a productivity of $3.14\left(\mathrm{~g} \mathrm{~L}^{-1} \mathrm{~h}^{-1}\right)$. 


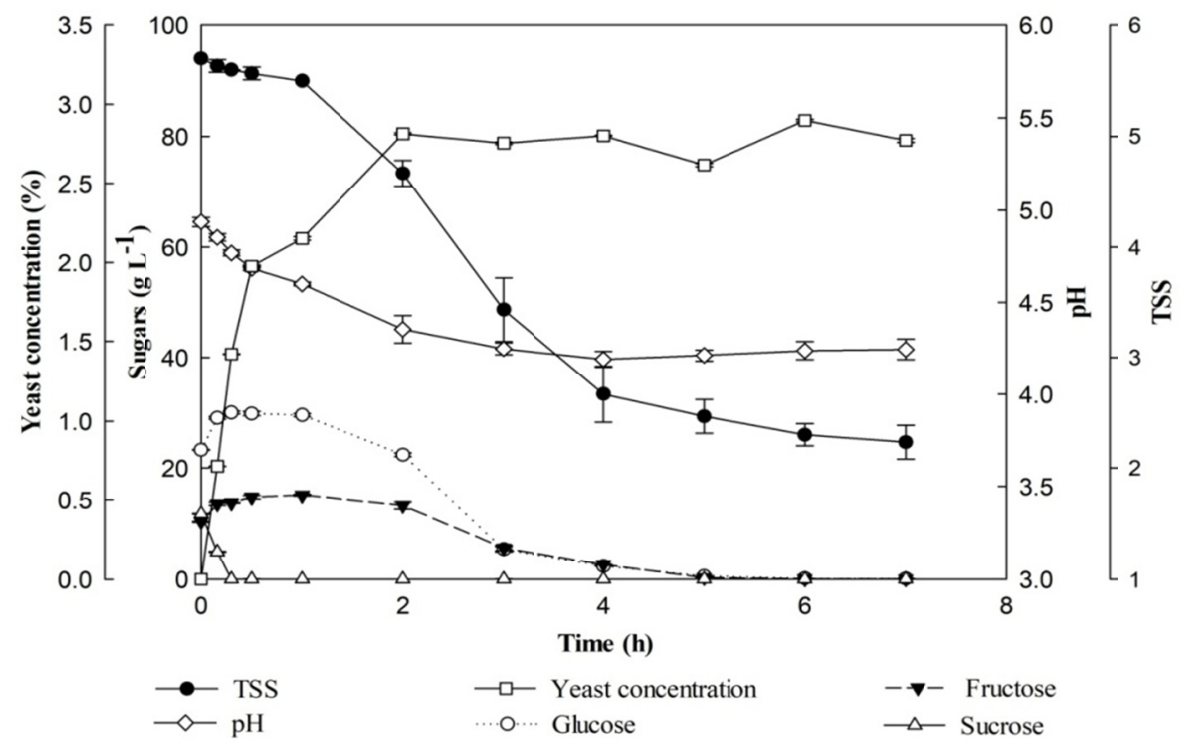

Figure 2. Fermentation kinetics of sugary cassava wort after $7 \mathrm{~h}$. Sugars consumption profile (glucose, fructose, and sucrose), TSS (total soluble solids) consumption profile, Yeast concentration (CAT-1 yeast strain), and pH evolution. Results are the mean of triplicate

\section{Discussion}

The physicochemical composition of the sugary cassava root (Table 1), showed high moisture content and a higher amount of starch than previously reported (Carvalho, Souza, Cascardo, Júnior, \& Campos, 2004; Souza, Bentes, Ladeira, Lopes, \& Pena, 2013). On the other hand, the chemical compositions found in the sugary cassava roots (Table 2) were close to those obtained by Souza et al. (2013) and Souza, Pereira, França, and Corrêa (2014), which obtained values of total soluble solids above 6\%. It interesting to highlight that the sugar content present in the root is considered low compared to sugar cane, which can reach levels above $20 \%$ (Silva et al., 2017).

It was found that the highest alcoholic concentrations obtained occurred from higher yeast concentrations $\sim 10 \%$, temperature $\sim 31{ }^{\circ} \mathrm{C}$, and $\mathrm{pH} \sim 4.5$, except for run number 10 (Table 3). However, it is known that linear reasoning should not be applied to complex fermentative processes, as a series of interconnected factors determine the behavior of the system. This fact justifies the joint analysis of the proposed variables.

In Table 5 we can observe that both the mean and the variables temperature (linear term), yeast concentration (linear and quadratic term), and interaction between $\mathrm{pH}$ and temperature showed significance regarding the ethanol content, under the conditions presented and tested by the experimental design. However, although the other effects were not significant, it is possible to evaluate the trend they have shown for ethanol production. When analyzing the linear effects of the variables, one must pay attention to the positive or negative signs. Thus, $\mathrm{pH}(\mathrm{L})$, temperature (L), and yeast concentration (L) had positive effects on alcohol production, which means, in practice, that the increase in $\mathrm{pH}$ and temperature favors the production of ethanol. Based on our results the optimal fermentation condition, where occurred the highest alcohol production by the yeast CAT-1, was established at $\mathrm{pH} 4.9$, temperature $32.13^{\circ} \mathrm{C}$, and yeast concentration of $11.28 \mathrm{~g} \mathrm{~L}^{-1}$.

According to the studies reported by Tsunatu, Atiku, Samuel, Hamidu, and Dahutu (2017); Le and Le (2014); Nuanpeng, Thanonkeo, Yamada, and Thanonkeo (2016), the ideal $\mathrm{pH}$ range used in fermentation for ethanol production by $S$. cerevisiae is $4.0-5.5$. High $\mathrm{pH}$ values $(>5.8)$ result in a high concentration of protons in the fermentation medium, which alters the overall charge on the cell's plasma membrane (Masiero, Peretti, Trierweiler, \& Trierweiler, 2014). This can affect the permeability of essential nutrients when entering the cell, causing inefficient growth and therefore low conversion of ethanol (Tsunatu et al., 2017). However, S. cerevisiae CAT-1 has better fermentative performance against stressful aspects compared to the other yeasts, presenting better production of ethanol at $\mathrm{pH} 5$ (Fernandes et al., 2020). It is believed that $S$. cerevisiae CAT-1 as an industrial yeast, presents dominant and resistant physiological aspects, which guarantee its permanence in stressful environments due to its superiority and adaptation compared to other yeasts (Stambuk, Dunn, Alves, Duval, \& Sherlock, 2009). Thus, fermentation with S. cerevisiae CAT-1 presents advantages for the industrial 
process, e.g., reduced foam formation, flocculation, and consumption of inputs. An acidic $\mathrm{pH}$ is important for controlling bacterial contamination in the industrial process. Although, in plants, a reduction in $\mathrm{pH}$ to $2.0-3.0$ through the use of $\mathrm{H}_{2} \mathrm{SO}_{4}$ has been adopted for a few hours to control bacterial contamination, this can cause physiological disturbances in yeast, causing a decrease in cell viability (Della-Bianca, Hulster, Pronk, Van Maris, \& Gombert, 2014).

Regarding the optimization of the yeast concentration, Souza et al. (2014), working with the S. cerevisiae PE-2 in a Box-Behnken Design (BBD), found the initial yeast concentration of $10 \mathrm{~g} \mathrm{~L}^{-1}$ to be optimal, reaching the maximum ethanol production of $0.78^{\circ} \mathrm{GL}$. For Shokrkar, Ebrahimi, and Zamani (2017) the optimization of the yeast concentration is one of the best-known techniques to improve the efficiency of the fermentation process.

The temperature found in this work showed to have a strong relationship with yeast growth. Similarly, Lin et al. (2012), analyzing the factors that affect alcoholic fermentation, found that maximum rates of ethanol production were obtained at $30-45^{\circ} \mathrm{C}$, achieving higher ethanol production at $30{ }^{\circ} \mathrm{C}$ with different glucose concentrations. According to Mukherjee et al. (2017) and Camargo et al. (2018), S. cerevisiae CAT-1 is able to tolerate high temperatures $\left(\sim 40{ }^{\circ} \mathrm{C}\right)$ and showed capacity to fermented sugars such as glucose, fructose, sucrose, mannose, maltose, raffinose and galactose, while other sugars such as xylose, cellobiose, mannitol and lactose cannot be fermented by this strain.

As shown in Figure 2, a rapid consumption of sucrose occurred shortly after the introduction of yeast in the fermentation medium, probably due to the action of extracellular invertase, which hydrolyzes sucrose into glucose and fructose (Margetić \& Vujčić, 2017; Marques et al., 2017; Fernandes et al., 2020). Therefore, there is a rapid increase in these sugars in the same proportion as sucrose decreases.

The low sugar concentration in this study was not a limiting factor for ethanol production, since lower growth rates of $S$. cerevisiae occur in high concentrations of sugars (200-300 $\left.\mathrm{g} \mathrm{L}^{-1}\right)$, as reported by Nuanpeng et al. (2016). Fast consumption of sugars probably occurred due to its low concentration in the medium, which does not require a long period of adaptation by the yeasts.

\section{Conclusion}

This study illustrates the huge potential sugary cassava has for ethanol production. The plant stores free sugars in greater quantity, as an energy source, in its roots (about $5.8 \%$ of its composition in fresh mass), which favors the direct fermentation process. We observed that the maximum concentration of ethanol produced after fermentation was $2.92 \%(\mathrm{v} / \mathrm{v})$, in its original conditions of chemical properties, which means 23.1 grams of alcohol per liter of wort. In addition, we also observed that an increase in temperature and yeast concentration had a positive effect on ethanol production. The $\mathrm{pH}$ range studied showed that a $\mathrm{pH}$ slightly acidic is preferable by the yeast strain used.

\section{References}

AOAC (Association of Official Analytical Chemists). (1984). Official Methods of Analysis of A.O.A.C. (14th ed.). Washington, DC.

AOAC (Association of Official Analytical Chemists). (1997). Official Methods of Analysis of A.O.A.C. International (16th ed., p. 1141). A.O.A.C. International, Gaithersburg, MD.

Basso, L. C., Amorim, H. V., Oliveira, A. J., \& Lopes, M. A. (2008). Yeast selection for fuel ethanol production in Brazil. FEMS Yeast Research, 8(7), 1155-63. https://doi.org/10.1111/j.1567-1364.2008.00428.x

Bligh, E. G., \& Dyer, W. J. (1959). A rapid method of total lipid extraction and purification. Canadian Journal of Biochemistry and Physiology, 34, 911-917. https://doi.org/10.1139/y59-099

BWC (Biofuels Watch Center). (2010). Brazil of Biofuels 2009: Impacts of Crops on Land, Environment and Society (Volume 6: Sugarcane). ONG Repórter Brasil. Retrieved September 7, 2020, from https://reporterbrasil.org.br/documentos/brazil_of_biofuels_v6.pdf

Camargo, J. Z., Nascimento, V. M., Stefanello, I., de Andrade Silva, C. A., Gonçalves, F. A., Perdomo, I. C., ... Fonseca, G. G. (2018). Biochemical evaluation, molecular characterization and identification of novel yeast strains isolated from Brazilian savannah fruits, chicken litter and a sugar and alcohol mill with biotechnological potential for biofuel and food industries. Biocatalysis and Agricultural Biotechnology, 16, 390-399. https://doi.org/10.1016/j.bcab.2018.09.006

Carneiro, M., Pradelle, F., Braga, S., Gomes, M., Martins, A., Turkovics, F., \& Pradelle, R. (2017). Potential of biofuels from algae: Comparison with fossil fuels, ethanol and biodiesel in Europe and Brazil through life cycle assessment (LCA). Renewable and Sustainable Energy Reviews, 73, 632-653. https://doi.org/10.1016/ 
j.rser.2017.01.152

Carvalho, L. J. C. B., Souza, C. R., Cascardo, J. C. M., Júnior, C. B., \& Campos, L. (2004). Identification and characterization of a novel cassava (Manihot esculenta Crantz) clone with high free sugar contentand novel starch. Plant Molecular Biology, 56(4), 643-659. https://doi.org/10.1007/s11103-004-4873-9

Creutzig, F., Ravindranath, N. H., Berndes, G., Bolwig, S., Bright, R., Cherubini, F., ... Fargione, J. (2015). Bioenergy and climate change mitigation: An assessment. Global Changes Biology Bioenergy, 7, 916-44. https://doi.org/10.1111/gcbb.12205

Della-Bianca B. E., Hulster, E., Pronk, J. T., Van Maris, A. J. A., \& Gombert, A. K. (2014). Physiology of the fuel ethanol strainSaccharomycescerevisiaePE-2 at low $\mathrm{pH}$ indicates a context-dependent performance relevant for industrial applications. FEMS Yeast Research, 14, 1196-1205. https://doi.org/10.1111/ $1567-1364.12217$

FAO (Food and Agriculture Organization of the United Nations). (2020). Faostat. Retrieved from http://www.fao.org/faostat/en/\#data/QC

Fernandes, A. M. O., Garcia, N. F. L., Fonseca, G. G., Leite, R. S. R., \& Paz, M. F. (2020). Evaluation of the Fermentative Capacity of Saccharomyces cerevisiae CAT-1 and BB9 Strains and Pichia kudriavzevii BB2 at Simulated Industrial Conditions. Indian Journal of Microbiology. https://doi.org/10.1007/s12088020-00891-6

Gomes, M., Biondi, A., Brianezi, T., \& Glass, V. (2010). Brazil of Biofuels: Impacts of Crops on Land, Environment and Society-Sugarcane 2009. Repórter Brasil Biofuel Watch Center, São Paulo, Brazil. Retrieved September 7, 2020, from http://www.reporterbrasil.org.br/documentos/brazil_of_biofuels_v6.pdf

Kristensen, S. B. P., Birch-Thomsen, T., Rasmussen, K., Rasmussen, L. V., \& Traoré, O. (2014). Cassava as an energy crop: A case study of the potential for an expansion of cassava cultivation for bioethanol production in Southern Mali. Renewable Energy, 66, 381-390. https://doi.org/10.1016/j.renene.2013.12.021

Le, H. D. T., \& Le, V. V. M. (2014). Effects of initial pH value of the medium on the alcoholic fermentation performance of Saccharomyces cerevisiae cells immobilized on nipa leaf sheath pieces. Songklanakarin Journal of Science and Technology, 36(6), 663-667. Retrieved from http://rdo.psu.ac.th/sjstweb/journal/ 36-6/36-6-9.pdf

Lima, U. A., Aquarone, E., Borzani, W., \& Schimidell, W. (2001). Biotecnologia Industrial: Processos Fermentativos e Enzimáticos (Volume 3, p. 593). São Paulo: Edgard Blücher.

Lin, Y., Zhang, W., Li, C., Sakakibara, K., Tanaka, S., \& Kong, H. (2012). Factors affecting ethanol fermentation using Saccharomyces cerevisiae BY4742. Biomass and Bioenergy, 47, 395-401. https://doi.org/10.1016/j.biombioe.2012.09.019

Margetić, A., \& Vujčić, Z. (2017). Comparative study of stability of soluble and cell wall invertase from Saccharomyces cerevisiae. Preparative Biochemistry and Biotechnology, 47(3), 305-311. https://doi.org/ 10.1080/10826068.2016.1244683

Marques, W. L., Mans, R., Marella, E. R., Cordeiro, R. L., Van Den Broek, M., Daran, J. G., .. Van Maris, J. A. (2017). Elimination of sucrose transport and hydrolysis in Saccharomyces cerevisiae: A platform strain for engineering sucrose metabolism. FEMS Yeast Research, 17, 1-11. https://doi.org/10.1093/femsyr/fox00

Masiero, S. S., Peretti, A., Trierweiler, L. F., \& Trierweiler, J. O. (2014). Simultaneous cold hydrolysis and fermentation of fresh sweet potato. Biomass Bioenergy, 70, 174-183. https://doi.org/10.1016/j.biombioe. 2014.08.007

Mukherjee, V., Radecka, D., Aerts, G., Verstrepen, K. J., Lievens, B., \& Thevelein, J. M. (2017). Phenotypic landscape of non-conventional yeast species for different stress tolerance traits desirable in bioethanol fermentation. Biotechnol Biofuels, 10, 216. https://doi.org/10.1186/s13068-017-0899-5

Nuanpeng, S., Thanonkeo, S., Yamada, M., \& Thanonkeo, P. (2016). Ethanol production from sweet sorghum juice at high temperatures using a newly isolated thermotolerant yeast Saccharomyces cerevisiae DBKKU Y-53. Energies, 9(4), 253. https://doi.org/10.3390/en9040253

Pradhan, P., Mahajani, S. M., \& Arora, A. (2018). Production and utilization of fuel pellets from biomass: A review. Fuel Processing Technology, 181, 215-232. https://doi.org/10.1016/j.fuproc.2018.09.021

Santos, R. M., Nogueira, F. C. S., Brasil, A. A., Carvalho, P. C., Leprevost, F. V., Domont, G. B., \& Eleutherio, E. C. A. (2017). Quantitative proteomic analysis of the Saccharomyces cerevisiae industrial strains CAT-1 
and PE-2. Journal of Proteomics, 151, 114-121. https://doi.org/10.1016/j.jprot.2016.08.020

Shokrkar, H., Ebrahimi, S., \& Zamani, M. (2017). Bioethanol production from acid and enzymatic hydrolysates of mixed microalgae culture. Fuel, 200, 380-386. https://doi.org/10.1016/j.fuel.2017.03.090

Silva, L. A., Gasparini, K., Assis, C., Ramos, R., Kist, V., Barbosa, M. H. P., ... Bhering, L. L. (2017). Selection strategy for indication of crosses between potential sugarcane genotypes aiming at the production of bioenergy. Industrial Crops and Products, 104, 62-67. https://doi.org/10.1016/j.indcrop.2017.04.025

Sipra, A. T., Gao, N., \& Sarwar, H. (2018). Municipal solid waste (MSW) pyrolysis for bio-fuel production: A review of effects of MSW components and catalysts. Fuel Processing Technology, 175, 131-147. https://doi.org/10.1016/j.fuproc.2018.02.012

Souza, H. A. L., Bentes, A. S., Ladeira, T. M. S., Lopes, A. S., \& Pena, R. S. (2013). Physicochemical properties of three sugary cassava landraces. Ciência Rural, 43(5), 792-796. https://doi.org/10.1590/S0103-84782 013000500006

Souza, L. S. S., Pereira, A. M., França, L. F., \& Corrêa, N. C. F. (2014). Otimização dos parâmetros operacionais da fermentação alcoólica da mandioca doce (Manihot esculenta Crantz). Revista Brasileira de Produtos Agroindustriais, 16(2), 147-154. Campina Grande. https://doi.org/10.15871/1517-8595/rbpa.v16n2p147-154

Sperotto, R. A. (2014). Protocolos e métodos de análise em laboratórios de biotecnologia agroalimentar e de saúde humana (1st ed., Volume 1, p. 329). Lajeado: Univates.

Stambuk, B. U., Dunn, B., Alves, S. L. Jr., Duval, E. H., \& Sherlock, G. (2009). Industrial fuel ethanol yeasts contain adaptive copy number changes in genes involved in vitamin B1 and B6 biosynthesis. Genome Research, 19, 2271-2278. https://doi.org/10.1101/gr.094276.109

Starzack, M., Kryzstek, L., Lech, N., \& Michalski H. (1994). Macroapproach kinetics of ethanol fermentation by Saccharomyces cerevisiae: Experimental studies and mathematical modelling. The Chemical Engineering Journal, 54, 221-240. https://doi.org/10.1016/0923-0467(94)00210-X

Stitt, M., Lilley, R. M. C., Gerhardt, R., \& Heldt, H. W. (1989). Metabolite levels in specific cells and subcellular compartments of plant leaves. Methods in Enzymology, 174, 518-552. https://doi.org/ 10.1016/0076-6879(89)74035-0

Trethewey, R. N., Geigenberger, P., Riedel, K., Hajirezaei, M. R., Son-Newald, U., Stitt, M., ... Willmitzer, L. (1998). Combined expression of glucokinase and invertasein potato tubers leads to a dramatic reduction in starch accumulation and a stimulation of glycolysis. Plant Journal, 15, 109-118. https://doi.org/10.1046/ j.1365-313X.1998.00190.x

Tsunatu, D., Atiku, K., Samuel, T., Hamidu, B., \& Dahutu, D. (2017). Production of bioethanol from rice straw using yeast extracts peptone dextrose. Nigerian Journal of Technology, 36(1), 296-301. https://doi.org/ 10.4314/njt.v36i1.36

Wangpor, J., Prayoonyong, P., Sakdaronnarong, C., Sungpet, A., \& Jonglertjunya, W. (2017). Bioethanol production from cassava starch by enzymatic hydrolysis, fermentation and ex-situ nanofiltration. Energy Procedia, 138, 883-888. https://doi.org/10.1016/j.egypro.2017.10.116

Zhang, M., Xie, L., Yin, Z., Khanal, S. K., \& Zhou, Q. (2016). Biorefinery approach for cassava based industrial wastes: Current status and opportunities. Bioresource Technology, 215, 50-62. https://doi.org/10.1016/ j.biortech.2016.04.026

\section{Copyrights}

Copyright for this article is retained by the author(s), with first publication rights granted to the journal.

This is an open-access article distributed under the terms and conditions of the Creative Commons Attribution license (http://creativecommons.org/licenses/by/4.0/). 